\title{
Optimization of Electric Field Parameters for HT29 Cell Line towards Wound Healing Application
}

\author{
Hassan Buhari Mamman ${ }^{1,2}$, Muhammad Mahadi Abdul Jamil ${ }^{1 *}$ and Mohamad Nazib Adon ${ }^{1}$ \\ 'Biomedical Engineering Modelling and Simulation (BIOMEMS) Research Group, \\ Department of Electrical and Electronics Engineering, University Tun Hussein Onn Malaysia, Johor, \\ Malaysia; mahadi@uthm.edu.my, Nazib@uthm.edu.my \\ ²Electrical and Electronics Engineering Department, Faculty of Engineering and Engineering Technology, \\ Abubakar Tafawa Balewa University Bauchi, Bauchi, Nigeria; buharimamman2007@yahoo.com
}

\begin{abstract}
Objective: The aim of this study is to optimize the electric field parameter for HT-29 cells line towards wound healing application. Methods: Cells were harvested when they reached $70 \%$ to $80 \%$ confluent. Afterward, $800 \mu \mathrm{l}$ of the cells suspension were poured into a $4 \mathrm{~mm}$ cuvette and placed in the BTX ECM 830 Electroporator chamber. Voltages in the range of $80 \mathrm{~V}$ to $800 \mathrm{~V}$ and pulse durations in the range of $100 \mu$ s to $10 \mathrm{~ms}$ were used in electroporating the cells. After treatment, $300 \mu \mathrm{l}$ of the cells suspension from each sample were seeded in a well of 6-wells plates each containing $2 \mathrm{ml}$ of pre-warm complete growth medium and incubated at $37^{\circ} \mathrm{C}$ and $5 \% \mathrm{CO}_{2}$ for 48 hours. Findings: The results obtained in this research quantitatively reveal the dependence of cell proliferation on electrical parameters. 200, 400, 600 and $800 \mathrm{~V} / \mathrm{cm}$ electric field strengths at duration of $500 \mu \mathrm{s}$ showed $42 \%, 63 \%, 86 \%$ and $36 \%$ increase in proliferation rate after 48 hours in culture as compared to initial plating densities, respectively. The control group and $1000 \mathrm{~V} / \mathrm{cm}$ at $100 \mu$ s showed $48 \%$ and $33 \%$ increase in proliferation rate respectively as compared to initial seeding density. While electric field strengths of $1200-2000 \mathrm{~V} / \mathrm{cm}$ at $200 \mathrm{~V} / \mathrm{cm}$ interval and at $100 \mu \mathrm{s}$ duration, revealed a decrease in proliferation rate by $4 \%, 15 \%, 18 \%$, $23 \%$ and $26 \%$ respectively as compared to initial seeding density. Applications: It was found that $600 \mathrm{~V} / \mathrm{cm}$ at $500 \mu$ sinduced the highest proliferation rate (86\%) as compared to initial seeding density after 48 hours of culture (that is $38 \%$ greater than the control group). This study can further be investigated for the use of the pulse electric field in facilitating drug-free wound healing process.
\end{abstract}

Keywords: Electroporation, Electric Field, Optimization, Proliferation, Wound Healing

\section{Introduction}

Electroporation is a general technique applicable to diverse cell type and hence, can be used for various purposes 1 . For instance, it is used for cell fusion, electrochemotherapy and gene therapy in medicine ${ }^{2}$, whereas it is also used for sterilization of liquid drug, food and water and transfection of bacteria in biotechnology ${ }^{2}$.

For a successful treatment, is a prerequisite to comprehends the mechanism of electroporation and also optimize most of the parameters that affect it. Hence, electroporation parameters must be precisely optimized for different applications and different cell types.

In an experimental setup, electroporation is performed by insertion of a biological sample between two electrodes and supplying an electric pulse to the electrodes, thereby, creating an electric field between the electrodes ${ }^{2}$. In different electroporation applications, efficiency is interpreted differently, depending on the required output. For instance, in electro-transfection, which involve loading of ions, DNA and molecules, electroporation efficiency is related to the number of cells loaded with the molecules that also survive the treatment, whereas in the sterilization of liquid food and drug and in tissue ablation, the efficiency of electroporation is related to the killing of the highest number of cells during the experimentation?2.

The efficient electroporation is achieved only by fine-tuning of the pulse parameters, among which pulse strength and pulse width or duration have the biggest influence on the outcome of the experiment. Each spe-

${ }^{*}$ Author for correspondence 
cific electroporation applications require to some extent different settings of pulse parameters. Moreover, pulse parameters need to be adjusted for a particular cell type, cell orientation, cell size and density of cells. Meaning that they can differ significantly even within a given application of electroporation? 2 .

A number of studies have studied the influence of pulse parameters on the efficiency of electroporation ${ }^{3-5}$. Altogether, these studies revealed that the same efficiency can be obtained with different combinations of pulse parameters. In most of these studies, electroporation efficiency was evaluated, either as the cells viability or fractions of electroporated cells. However, the target of our study is for potential application in the proliferative stage of wound healing process, where cells are required to proliferate and spread to cover the wound edges. Hence, in this study, the efficiency of electroporation was determined by measuring the percentage cell proliferation (growth rate) and percentage increase in cell length (cell spreading) of the electroporated cells.

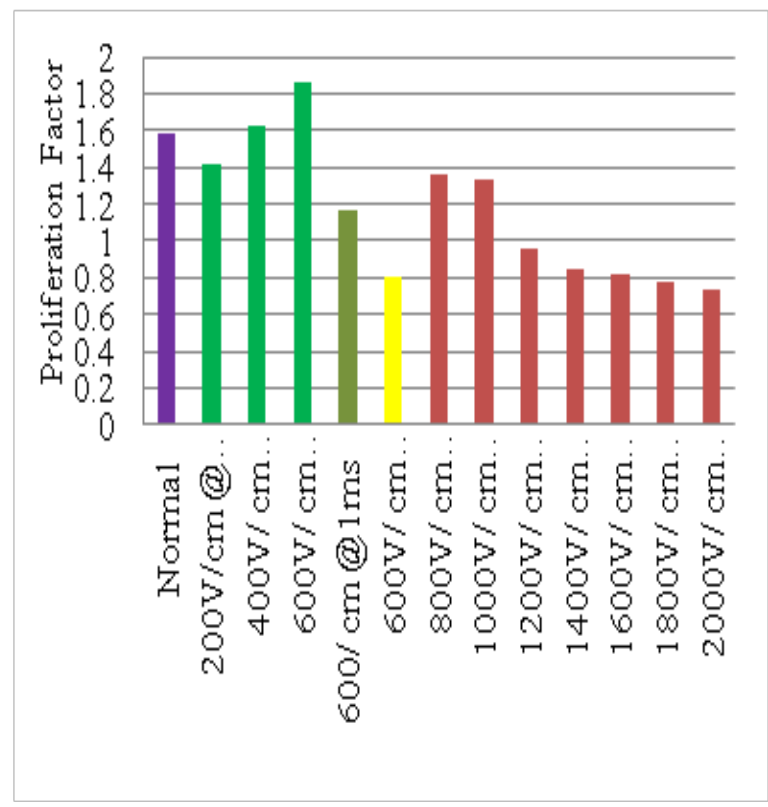

Figure 1. HT29 proliferation factor for different electric field parameters.

\section{Methodologies}

\subsection{Cell Culture}

In this study, HT-29 cells line were used for carrying out the experiments. The colon cells line were cultured as a monolayer in RPMI1640 enhanced with $10 \%$ Fetal Bovine Serum (FBS) and 1\% antibiotic (penicillin and streptomycin) all from Gibco USA. The cells were grown in a humidified incubator at $37^{\circ} \mathrm{C}$, containing $5 \% \mathrm{CO}_{2} \frac{6,7}{2}$. Cells were sub-cultured every 3 to 5 days whenever they reached $80 \%$ to $90 \%$ confluent $^{6}$. For subculture, the old medium was first aspirated and discarded. Then $3 \mathrm{ml}$ of Phosphate Buffer Saline (PBS) was added for washing the cells $s^{7.8}$. The added PBS was aspirated and discarded.

Subsequently, two milliliters $(2 \mathrm{ml})$ of the Tryple Express solution was added for cells detachment $\frac{7,8}{\text {. }}$. The cells plus the Tryple Express were incubated for 5-10 minutes at $5 \% \mathrm{CO}_{2}$ at $37^{\circ} \mathrm{C}$. This is because of the Tryple Express works well in a warm environment. When the cells were fully detached, an equal volume of complete growth medium was added to stop the effect of the Tryple Express. Subsequently, the cells were re-suspended to a uniform suspension.

\subsection{Electroporation}

The commercial electroporator ECM830 made from BTX Harvard Apparatus was used for electroporating the cells line in suspension. The ECM830 has two modes of operation: The first mode is a low voltage mode with output voltage ranging from $5 \mathrm{~V}$ to $500 \mathrm{~V}$ and pulses length of 10 $\mathrm{ms}$ to $999 \mathrm{~ms}$ (1 ms resolution). Second is the high voltage mode with output voltage ranging from $501 \mathrm{~V}$ to $3 \mathrm{KV}$ and pulses duration of $10 \mu$ s to $600 \mu$ s ( $1 \mu$ s resolution).

After harvesting the cells with Tryple Express and neutralizing with an equal volume of complete growth medium as explained earlier Section 2.1. Eight hundred microliter $(800 \mu \mathrm{l})$ of cells suspension at a concentration of $3.92 \times 10^{5} \mathrm{cells} / \mathrm{ml}$, was then poured into a $4 \mathrm{~mm}$ electrode gap cuvette (BTX Harvard Apparatus). An electric field with an intensity of ranging from $200-2000 \mathrm{~V} / \mathrm{cm}$ at $200 \mathrm{~V} / \mathrm{cm}$ interval were used in electroporating the cells (i.e. a voltage range of $80-800 \mathrm{~V}$ at $80 \mathrm{~V}$ interval; for 4 $\mathrm{mm}$ electrode gap cuvette). Between 200-800 V/cm field strength, $500 \mu$ s pulse duration was utilized. On the other hand, $100 \mu$ s was used for field strength between 1000 $2000 \mathrm{~V} / \mathrm{cm}$.

Subsequently, a $300 \mu \mathrm{l}$ volume of cells (representing 117,600 cells) were then seeded into a 6-wells plates containing $2 \mathrm{ml}$ of complete growth medium (cell density of $5.88 \times 10^{4}$ cells $/ \mathrm{ml}$ ) and were incubated at $37^{\circ} \mathrm{C}$ and $5 \%$ of $\mathrm{CO}_{2}$. Similarly, as control, 294, 000 cells from the same initial flask but without electroporation were 
also seeded in another well, containing $2 \mathrm{ml}$ of complete growth medium. Both flasks are cultured under the same condition for 48 hours.

\subsection{Measurement of Cell Proliferation}

After 48 hours in culture, cells were detached and counted using hemocytometer, for each treatment. Cells densities after 48 hours were compared with the initial plating density $\left(5.88 \times 10^{4}\right.$ cells $\left./ \mathrm{ml}\right)$. A proliferation factor was computed by dividing cell density after 48 hours in culture by the initial cell plating density. The experiments were performed in triplicate for consistency, and the mean proliferation factor was calculated.

\subsection{Measurement of Cell Length}

For each treatment used (Control and EPs), cells sizes were determined after 48 hours in culture by the acquisition of photomicrographs and measurement using MetaMorph software. The experiments were repeated three times. Average cells sizes were normalized for all groups and presented as a percentage increase or decrease in cell size as compared to final cell size in control group. Sixty (60) cells were analysed in each of the triplicate experiments, i.e. a total of one hundred and eighty (180) cells were measured. Note that MetaMorph software measures the length of the object as the span of the longest chord through the object.

\section{Experimental Results}

The efficiency of electroporation depends on many physical parameters (electric field parameters) and biological parameters (cell state and geometry). In electroporation applications, electric field parameters are usually adjusted to specific cell parameters and biomedical or biotechnology applications i.e. electroporation objectives ${ }^{9}$. Nonetheless, some parameters are more significant than the others. For instance, it is very vital to fine-tune pulse amplitude to specific cell size and pulse duration to a particular objective. Even though, these parameters finetuning are not easy, as the electric field parameters are interconnected to some degree as regards the electroporation efficiency i.e. same level of electroporation can be achieved with $\mathrm{E}_{1} \mathrm{~T}_{1}$ or $\mathrm{E}_{2} \mathrm{~T}_{2}$ ( E electric field strength and $\mathrm{T}$ pulse duration). Note that $\mathrm{E}_{1}>\mathrm{E}_{2}$ and $\mathrm{T}_{1}<\mathrm{T}_{2}$.

The results obtained in this research, as shown in Table 1 and Figure 1 quantitatively revealed the dependence of cell proliferation on electrical parameters. Pulse amplitude of 200, 400, 600 and $800 \mathrm{~V} / \mathrm{cm}$, each with duration of $500 \mu$ s, showed $42 \%, 63 \%, 86 \%$ and $36 \%$ increase in proliferation rate respectively, after 48 hours in culture as compared to initial plating density. The control group reveals a $48 \%$ increase in proliferation rate, which are 1.48 proliferation factors. Further, increasing the electric field from $1000 \mathrm{~V} / \mathrm{cm}$ to $2000 \mathrm{~V} / \mathrm{cm}$ at $200 \mathrm{~V} / \mathrm{cm}$ intervals and $100 \mu$ s pulse duration revealed a subsequent decrease in proliferation factors to $1.33,0.96,0.85,0.82,0.77$ and 0.74 respectively as compared to the control group. Note that proliferation factor of less than one is showing a decrease in proliferation rate.

It was found that $600 \mathrm{~V} / \mathrm{cm}$ at $500 \mu$ induced the highest proliferation rate $(86 \%)$ as compared to initial seeding density after 48 hours of culture. The $600 \mathrm{~V} / \mathrm{cm}$ at $500 \mu$ s is $28 \%$ greater in proliferation rate than the control group. Higher electric field strengths were found to induce lower cell viability ${ }^{10}$ as shown in Table 3.

(Proliferation factor less than 1). When the pulse duration was increased from $500 \mu$ s to $1 \mathrm{~ms}$ and subsequently to $10 \mathrm{~ms}$ at fixed amplitude of $600 \mathrm{~V} / \mathrm{cm}$. There was a subsequent decrease in proliferation factor from 1.86 to 1.16 and then 0.8 respectively.

Similarly, cell length measurement after 48 hours in culture revealed that $600 \mathrm{~V} / \mathrm{cm} 500 \mu \mathrm{s}$ has the highest value of cell length measurement i.e. $21 \%$ increase as compared to control. Except for $600 \mathrm{~V} / \mathrm{cm} @ 1 \mathrm{~ms}$ and $10 \mathrm{~ms}$, that reveal a slight decrease in cell length as compared to control (10.5\% and $7.4 \%$ decrease), all other field parameters show a slight increase in cell length as compared to control (Table 2).

The results of the experiment showed that cell proliferation is considerably affected when treated with pulse electric field. Cell proliferation was found to increase with an increase in pulse amplitude from $200 \mathrm{~V} / \mathrm{cm}$ to $600 \mathrm{~V} / \mathrm{cm}$ at fixed duration of $500 \mu \mathrm{s}$. However, further increasing the pulse amplitudes from $600 \mathrm{~V} / \mathrm{cm}$ to 2000 $\mathrm{V} / \mathrm{cm}$ induced the down-regulation of the cell proliferation rate. At pulse strength of $2000 \mathrm{~V} / \mathrm{cm}$ and $100 \mu \mathrm{s}$ pulse duration, most of the cells are lysed. Qualitative observation of cell media at pulse strength greater than $1000 \mathrm{~V} / \mathrm{cm}$ showed a change in colour from red to orange. This could be due to the electrolysis of the media at higher pulse amplitude which resulted in a change in $\mathrm{pH}$ of the media from neutral to acidic. This change in $\mathrm{pH}$ could be attributed to the higher number of cell death at higher pulse amplitudes. 
Pulse amplitude of $600 \mathrm{~V} / \mathrm{cm}$ at $500 \mu$ s revealed the highest proliferation rate. This could be that the electric field $(600 \mathrm{~V} / \mathrm{cm}$ and $500 \mu \mathrm{s})$ assisted the cells in taken more nutrients from the media due the pore formation resulting from the field effect. Besides, it could be that the field is sub-lethal to the cells and created only some transient pores in the cells membrane. However, when the pulse strength was fixed at of $600 \mathrm{~V} / \mathrm{cm}$, varying the pulse duration from $500 \mu$ s to $1 \mathrm{~ms}$ and then $10 \mathrm{~ms}$, revealed a decrease in cell proliferation rate. The results of this study are in agreement qualitatively with the result reported by 11 .

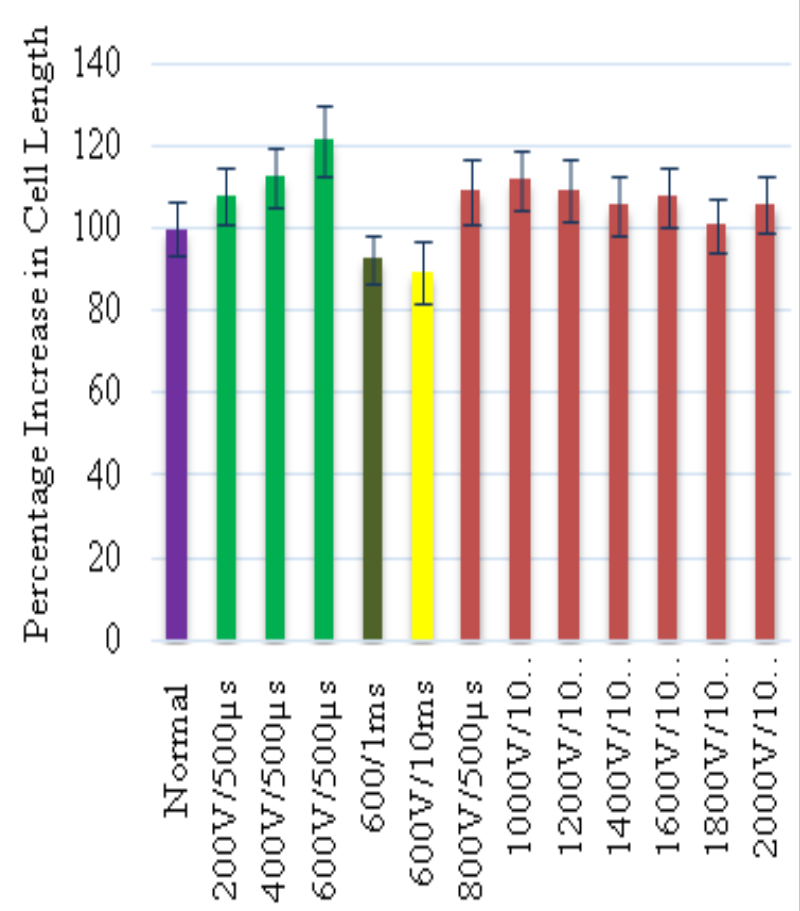

Figure 2. Percentage increase in HT29 cell line for different EP parameters.

The study showed that cell proliferation under the influence of electric field is voltage dependent ${ }^{12}$. The lower voltages between $400 \mathrm{~V} / \mathrm{cm}$ and $600 \mathrm{~V} / \mathrm{cm}$ at 500 $\mu$ duration facilitate the proliferation of HT29 cells line; with $600 \mathrm{~V} / \mathrm{cm}$ at $500 \mu$ s duration revealing the highest proliferation factor and cell spreading properties. On the other hand, higher field strengths from 1200 to $2000 \mathrm{~V} /$ $\mathrm{cm}$ at $100 \mu$ s duration, decrease the proliferation rate of HT29 cells line. Therefore, for an application like wound healing, where cell proliferation and spreading is needed to cover the wound site, $600 \mathrm{~V} / \mathrm{cm}$ at $500 \mu$ s could be utilized. Similarly, the higher voltages could be used for cell ablation in cancer cell treatment.

Table 1. HT29 proliferation factor for different electric field parameters

\begin{tabular}{|l|l|}
\hline Electroporation Parameter & $\begin{array}{l}\text { Proliferation Factor after } \\
48 \text { hours }\end{array}$ \\
\hline Normal & 1.48 \\
\hline $200 \mathrm{~V} / \mathrm{cm} @ 500 \mu \mathrm{s}$ & 1.42 \\
\hline $400 \mathrm{~V} / \mathrm{cm} @ 500 \mu \mathrm{s}$ & 1.63 \\
\hline $600 \mathrm{~V} / \mathrm{cm} @ 500 \mu \mathrm{s}$ & 1.86 \\
\hline $600 / \mathrm{cm} @ 1 \mathrm{~ms}$ & 1.16 \\
\hline $600 \mathrm{~V} / \mathrm{cm} @ 10 \mathrm{~ms}$ & 0.8 \\
\hline $800 \mathrm{~V} / \mathrm{cm} @ 500 \mu \mathrm{s}$ & 1.36 \\
\hline $1000 \mathrm{~V} / \mathrm{cm} @ 100 \mu \mathrm{s}$ & 1.33 \\
\hline $1200 \mathrm{~V} / \mathrm{cm} @ 100 \mu \mathrm{s}$ & 0.96 \\
\hline $1400 \mathrm{~V} / \mathrm{cm} @ 100 \mu \mathrm{s}$ & 0.85 \\
\hline $1600 \mathrm{~V} / \mathrm{cm} @ 100 \mu \mathrm{s}$ & 0.82 \\
\hline $1800 \mathrm{~V} / \mathrm{cm} @ 100 \mu \mathrm{s}$ & 0.77 \\
\hline $2000 \mathrm{~V} / \mathrm{cm} @ 100 \mu \mathrm{s}$ & 0.74 \\
\hline
\end{tabular}

Table 2. Percentage increase in HT29 cell line for different EP parameters

\begin{tabular}{|l|l|l|}
\hline $\begin{array}{l}\text { Electroporation } \\
\text { Parameter }\end{array}$ & $\begin{array}{l}\text { Length after } \\
48 \text { Hour } \\
(\mu \mathrm{m})\end{array}$ & $\begin{array}{l}\text { Percentage } \\
\text { increase in Length } \\
\text { after 48 hours (\%) }\end{array}$ \\
\hline Normal & 40.0 & 100.0 \\
\hline $200 \mathrm{~V} / \mathrm{cm} @ 500 \mu \mathrm{s}$ & 43.1 & 107.7 \\
\hline $400 \mathrm{~V} / \mathrm{cm} @ 500 \mu \mathrm{s}$ & 44.9 & 112.4 \\
\hline $600 \mathrm{~V} / \mathrm{cm} @ 500 \mu \mathrm{s}$ & 48.5 & 121.3 \\
\hline $600 / \mathrm{cm} @ 1 \mathrm{~ms}$ & 37.0 & 89.5 \\
\hline $600 \mathrm{~V} / \mathrm{cm} @ 10 \mathrm{~ms}$ & 35.8 & 92.6 \\
\hline $800 \mathrm{~V} / \mathrm{cm} @ 500 \mu \mathrm{s}$ & 43.5 & 108.9 \\
\hline $1000 \mathrm{~V} / \mathrm{cm} @ 100 \mu \mathrm{s}$ & 44.7 & 111.8 \\
\hline $1200 \mathrm{~V} / \mathrm{cm} @ 100 \mu \mathrm{s}$ & 43.7 & 109.2 \\
\hline $1400 \mathrm{~V} / \mathrm{cm} @ 100 \mu \mathrm{s}$ & 42.2 & 105.5 \\
\hline $1600 \mathrm{~V} / \mathrm{cm} @ 100 \mu \mathrm{s}$ & 43.1 & 107.7 \\
\hline $1800 \mathrm{~V} / \mathrm{cm} @ 100 \mu \mathrm{s}$ & 40.3 & 100.8 \\
\hline $2000 \mathrm{~V} / \mathrm{cm} @ 100 \mu \mathrm{s}$ & 42.3 & 105.8 \\
\hline
\end{tabular}




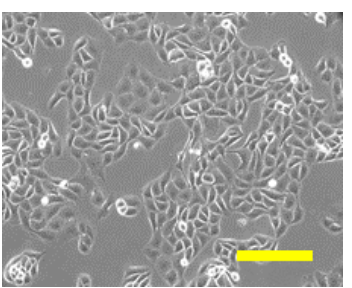

Normal

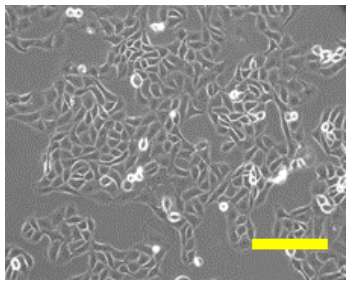

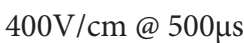

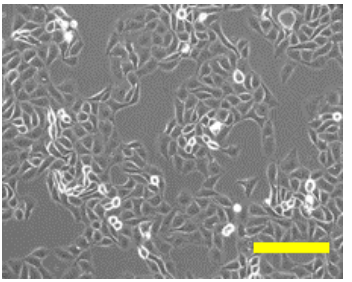

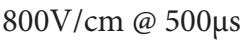

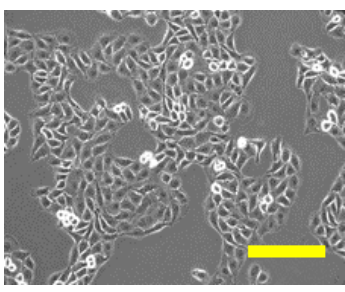

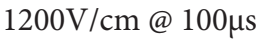

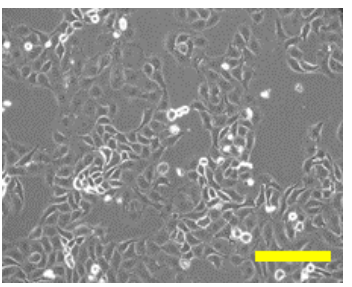

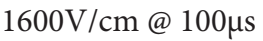

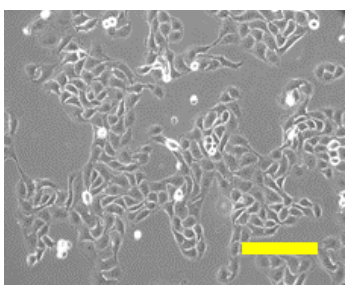

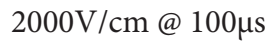

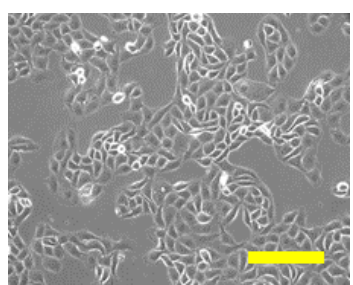

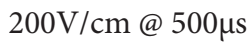

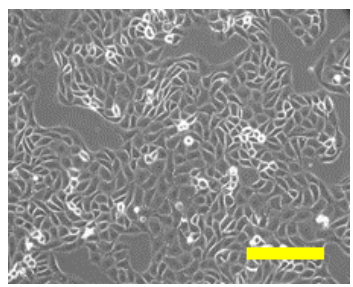

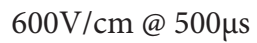

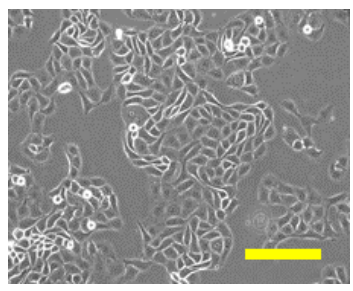

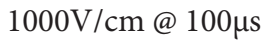

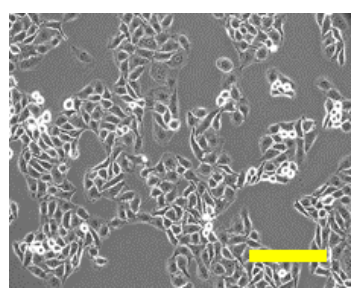

$1400 \mathrm{~V} / \mathrm{cm} @ 100 \mu \mathrm{s}$

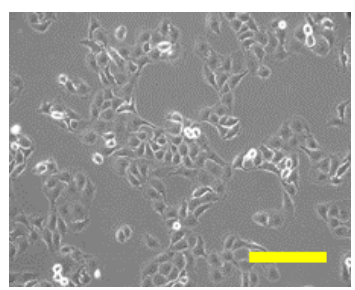

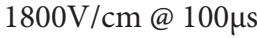

Figure 3. Photomicrograph of HT29 electroporated with various electric field parameters. The image represents one of the several field views for the triplicate experiment captured for analysis (Scale bar $=100 \mu \mathrm{m})$.

\section{Conclusion}

Since the same level of electroporation efficiency can be achieved with $\mathrm{E}_{1} \mathrm{~T}_{1}$ or $\mathrm{E}_{2} \mathrm{~T}_{2}$ (E electric field strength and T pulse duration), where $\mathrm{E}_{1}>\mathrm{E}_{2}$ and $\mathrm{T}_{1}<\mathrm{T}_{2}^{8}$, lower voltage ranges at moderate pulse duration have been chosen. This is because higher voltage could result to electrolysis of the media and reduce cell viability $\underline{\underline{13}}$.

Thus, the results revealed that HT29 cell proliferation rate is voltage dependent and the application of lower strength electrical pulse $(600 \mathrm{~V} / \mathrm{cm})$ within microsecond duration $(500 \mu \mathrm{s})$ could provide higher proliferation rate for wound healing application.

\section{Acknowledgment}

The Authors wish to thank the Ministry of Education Malaysia for financial support of this work through Prof. Madya Muhammad Mahadi Abdul Jamil (VOT 1488 Fundamental Research Grant Scheme (FRGS) Phase 2/2014 University Tun Hussein Onn Malaysia). We would also like to express our profound gratitude to Abubakar Tafawa Balewa University Bauchi, Nigeria, for Supporting Hassan Buhari Mamman to further his studies at University Tun Hussein Onn Malaysia.

\section{References}

1. Zupanic A. Treatment planning in biomedical applications of electroporation. [Ph.D thesis]. Slovenia: University of Ljubljana; 2010. p. 224.

2. Pucihar G, Krmelj J, Reberssek M, Napotnik T, Miklavcicc D. Equivalent pulse parameters for electroporation. IEEE Transactions on Biomedical Engineering. 2011 Sep; 58(11):3279-88.

3. Venslauskas M, Satkauskas S, Rodaite R. Efficacy of the delivery of small charged molecules into cells in vitro. Bioelectrochemistry. 2010 Oct; 79(1):130-5.

4. Krassowska W, Nanda G, Austin M, Dev S, Rabussay D. Viability of cancer cells exposed to pulsed electric fields: The role of pulse charge. Ann Biomed Eng. 2003 Jan; 31(1):80-90.

5. Canatella J, Karr J, Petros J, Prausnitz M. Quantitative study of electroporation-mediated molecular uptake and cell viability. Biophys J. 2001 Feb; 80(2):755-64.

6. Lye HS, Khoo BY, Karim AH, Rusul G, Liong MT. Growth properties and cholesterol removal ability of electroporated Lactobacillus acidophilus BT 1088. Journal of Microbiology and Biotechnology. 2012 Mar; 22(7):981-9. 
7. Mamman H, Abdul Jamil M. Investigation of electroporation effect on HT29 cell lines adhesion properties. 2015 IEEE 2nd International Conference on Biomedical Engineering (ICoBE); 2015 Mar 30-31. p. 1-5.

8. Mamman H, Sadiq A, Adon M, Abdul Jamil M. Study of electroporation effect on HT29 cell migration properties. 2015 IEEE International Conference on Control System, Computing, and Engineering (ICCSCE 2015); 2015 Nov 27-29. p. 342-6.

9. Rebersek M, Miklavcic D. Advantages and disadvantages of different concepts of electroporation pulse generation. Journal Automatika. 2011; 52(1):12-9.

10. Tryfona T, Bustard M. Impact of pulsed electric fields on Corynebacterium glutamicum cell membrane permeabili- zation. Journal of Bioscience and Bioengineering. 2008 Jan; 105(4):375-82.

11. Dubey A, Gupta S, Basu B. Optimization of electrical stimulation parameters for enhanced cell proliferation on Biomaterial surfaces. Journal of Biomedical Materials Research Part B: Applied Biomaterials. 2011 Feb; 98B(1):18-29.

12. Pehlivanova V, Tsoneva I, Tzoneva R. Influence of electroporation on cell adhesion, growth and viability of cancer cells and fibroblasts. Biologie Cellulaire. 2010 Dec; 64(4):581-90.

13. Saulis G, Lape R, Praneviciute R, Mickevicius D. Changes of the solution $\mathrm{pH}$ due to exposure by high-voltage electric pulses. Bioelectrochemistry. 2005 Sep; 67(1):101-8. 